\title{
Huntington's chorea in South Wales: mutation, fertility, and genetic fitness
}

\author{
D A WALKER*, P S HARPER, R G NEWCOMBE, AND KATHLEEN DAVIES \\ From the Section of Medical Genetics, Department of Medicine, \\ and Department of Medical Statistics, Welsh National School of Medicine, Heath Park, Cardiff.
}

SUMMARY A study of mutation, biological fitness, and patterns of family building in Huntington's chorea has been carried out, based on a previously reported population study of the disorder in : South Wales. No unequivocal new mutation was identified among 101 kindreds containing $418 \overrightarrow{\mathrm{N}}$ affected persons, which supports the extreme rarity of mutation in this disorder.

Increased values of fertility and fitness were found, both in relation to unaffected relatives and to the general population of the area. The proportion of unmarried persons and pattern of family building was comparable in affected and unaffected subjects, and no correlation with age at onset or mode of clinical presentation could be found.

There is ample evidence from pedigrees ${ }^{1-5}$ and twin studies $^{6}$ that Huntington's chorea (HC) follows autosomal dominant inheritance, with complete penetrance of the gene in those persons surviving into old age.

Since new mutations are exceedingly rare, the prevalence of $\mathrm{HC}$ must be maintained by transmission of the gene. Indeed, there is evidence, depending upon the control populations used, that heterozygotes have more children than expected. $^{35}$ 7-9 Further, fertility of female choreics has been reported to be higher than that of male choreics. $^{57810}$

Prevention of HC currently relies upon reducing the number of births at risk. An understanding of the factors underlying the extra fertility of patients with $\mathrm{HC}$ is thus directly relevant to any programme of long term prevention.

\section{Methods}

Between 1973 and 1978 an attempt was made to ascertain all affected and at risk subjects in Glamorgan and Gwent, South Wales. ${ }^{11} 12$ A total of 101 apparently unrelated pedigrees was discovered containing 418 affected persons and 2268 unaffected relatives. Near complete ascertainment was achieved.

The categories available for studying fertility of

* Present address: Barnes Hospital, Cheadle, Cheshire.

Received for publication 22 June 1982. affected persons, their non-affected offspring (here termed generation 1 or $\mathrm{G1}$ ), and unaffected subjects with a normal parent, but an affected grandparent (generation 2 or G2) were livebirths, stillbirths, and detected abortions. Abortions were discounted since information was often not available or was incomplete, even for relatively recent generations. There were 20 stillbirths in the study as a whole, 13 being included in the present analysis (two from affected male parents, five from affected female parents, three from G1 male and three from G1 female parents). Single persons and those with unknown civil status were excluded, except where specifically mentioned. Since validity of comparison depends upon completed families, only persons of 45 years and over were included.

Ideally, fitness and relative fitness should be $\frac{\text { ㅇ }}{2}$ assessed with a group of G1 controls containing no heterozygotes, that is, they should have attained an age when the risk of carrying the gene is small, $N$ say 60 years, when the remaining risk of heterozygosity is only 1 in 7 . Fitness and relative fitness in the present study were assessed by decade of birth, $\omega$ so the effect of heterozygote inclusion can be seen clearly.

In addition, an attempt was made to compare $\mathbb{D}$ affected and $\mathrm{G} 1$ subjects with the general population. The population figures do not include stillbirths and express data as mean ultimate family size per year of marriage. The study data were thus adjusted, assuming 25 years as an average age at marriage. 


\section{Results}

No affected person conformed to the criteria of Stevens and Parsonage ${ }^{13}$ as a new mutation. Information on possible mutations is scanty (table 1 ). The one isolated case which was a potential new mutation had had no affected children at the time of the survey. Using this case, assuming a heterozygote frequency of $20 \cdot 2$ per 100000 , the mutation rate becomes $1 \times 10^{-6}$ mutations per locus per generation.

The assessment of fertility (table 2 ) shows that affected subjects have significantly more children than unaffected (males $t=5.28, p<0.001$; females $t=2 \cdot 49, p<0 \cdot 05$ ). Unaffected subjects had a greater proportion of the small sized families, while the large families tended to be derived from choreic subjects. There was no significant difference in mean family size between the sexes of either affected or unaffected subjects, ron was there any difference in family size between $\mathrm{G} 1$ and $\mathrm{G} 2$ unaffected subjects.

The extra fertility of the affected group was 1.49 for males and 0.71 for females. When the figures are adjusted for cohort effect using a method of weighted means to adjust for date of birth, the extra fertility reduces to 1.06 and 0.34 . Thus, half the extra fertility in females and $30 \%$ in affected males can be explained as resulting from the founder effect of the inclusion of asymptomatic heterozygotes.

A further illustration of this appears in the decade of birth analysis (table 3 ). The mean family size of both affected and unaffected (G1) subjects declines to the 1910 to 1919 period, but increases thereafter, except in choreic females. The decline reflects a combination of effects, including the general decline in birth rate and the specific effect of World War 1.

Fitness measurements (tables 4,5 ) are similar to the fertility figures. That the biological fitness of $\mathrm{G} 1$ and $\mathrm{G} 2$ unaffected persons and the relative fitness of $\mathrm{G} 1$ persons compared to the general population
TABLE 1 Source of the HC gene in the 101 pedigrees. $A$ single ancestor refers to the earliest known family member. The gene in sibships, unless recessive inheritance is involved, must have come from a parent.

\begin{tabular}{lllll}
\hline & $\begin{array}{l}\text { No } \\
\text { information } \\
\text { available }\end{array}$ & $\begin{array}{l}\text { One parent } \\
\text { died } \\
<65 \text { years }\end{array}$ & $\begin{array}{l}\text { Both parents } \\
\text { dead or alive } \\
>65 \text { years }\end{array}$ & Total \\
\hline $\begin{array}{l}\text { Isolated } \\
\text { case }\end{array}$ & 14 & 11 & 1 & 26 \\
$\begin{array}{c}\text { Single } \\
\text { ancestor }\end{array}$ & 36 & 5 & - & 41 \\
Sibship & 23 & 8 & 3 & 34 \\
\hline
\end{tabular}

TABLE 2 Distribution of family size of affected and unaffected subjects (G1 and G2). Single persons are excluded.

\begin{tabular}{lllllll}
\hline \multirow{2}{*}{$\begin{array}{l}\text { Family } \\
\text { size }\end{array}$} & \multicolumn{5}{c}{ Males } & \multicolumn{5}{c}{ Females } \\
\cline { 2 - 7 } & Affected & $G I$ & $G 2$ & \multicolumn{2}{c}{ Affected G1 } & $G 2$ \\
\hline 0 & 10 & 21 & 3 & 19 & 22 & 1 \\
1 & 21 & 29 & 3 & 24 & 24 & 3 \\
2 & 21 & 44 & 7 & 37 & 44 & 8 \\
3 & 25 & 21 & 2 & 17 & 16 & 4 \\
4 & 16 & 5 & 2 & 16 & 9 & 1 \\
5 & 10 & 9 & - & 11 & 2 & 1 \\
6 & 12 & 6 & 1 & 9 & 6 & - \\
7 & 9 & 2 & - & 10 & 3 & - \\
8 & 2 & 2 & - & 3 & 5 & 1 \\
9 & 2 & - & - & 2 & 2 & - \\
10 & 4 & - & - & 3 & 1 & - \\
11 & 2 & - & - & 1 & - & - \\
12 & 2 & - & - & 1 & - & - \\
Mean & $3 \cdot 73$ & $2 \cdot 24$ & $2 \cdot 05$ & $3 \cdot 18$ & $2 \cdot 47$ & $2 \cdot 53$ \\
n & 136 & 139 & 18 & 153 & 134 & 19 \\
\hline
\end{tabular}

are close to unity further supports the use of $\mathrm{G} 1$ unaffected persons as an adequate control group. High values for fitness before 1900 and after 1920 confirm the influence of single ancestors and asymptomatic heterozygotes.

A further reason for the increased fitness seen in earlier decades could be less complete ascertainment of families with fewer offspring, in which there might well be no living affected members at the present time.

TABLE 3 Mean family size according to date of birth. Figures in brackets represent number of families from which figures are derived.

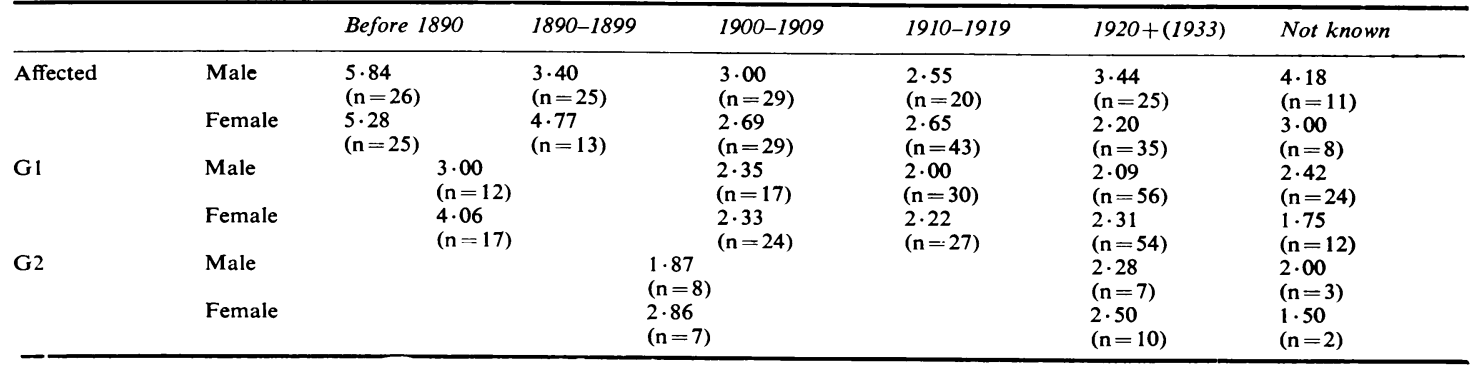


TABLE 4 Biological fitness according to decade of birth.

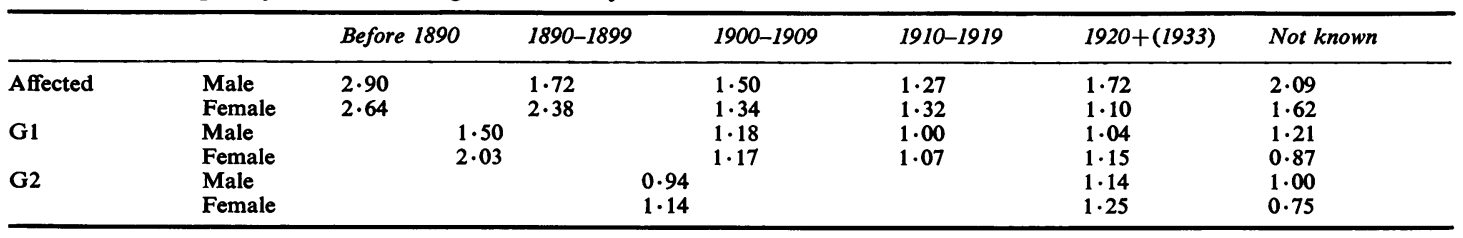

TABLE 5 Relative fitness $(W)$ of affected $(C)$, unaffected $(G 1)$, and the general population of Glamorgan and Gwent $(P)$ according to decade of birth.

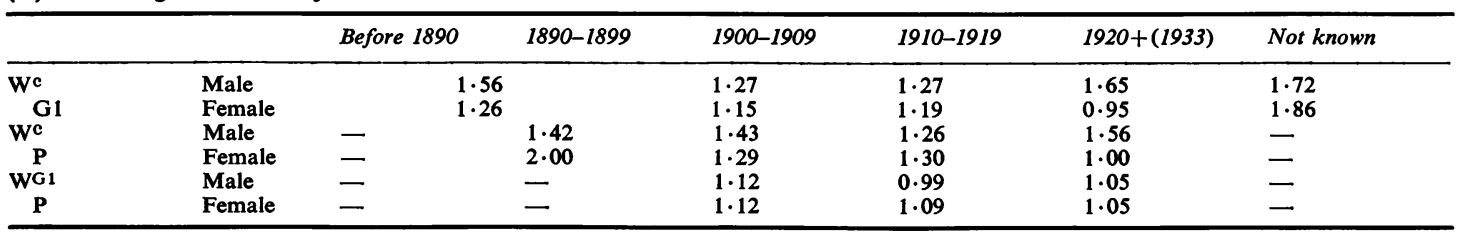

Since the above data relate to married subjects, it is important to exclude an effect of the $\mathrm{HC}$ gene on likelihood of marriage. The data in table 6 show that around $9 \%$ remain unmarried by the age of 45 , with very similar values for affected and unaffected (G1) subjects and for both sexes.

Family building (table 7) of affected persons is comparable with $\mathrm{G} 1$ unaffected persons. Females tend to start a family sooner, and for both sexes the age of a parent at the birth of the first child is younger in larger families, and these subjects may continue reproducing well into their forties. These

TABLE 6 Number of subjects unmarried by the age of 45 years.

\begin{tabular}{|c|c|c|c|}
\hline & Affected & Unaffected (GI) & Total \\
\hline $\begin{array}{l}\text { Male } \\
\text { Female } \\
\text { Total }\end{array}$ & $\begin{array}{l}14 / 137(10 \cdot 3 \%) \\
13 / 159(8 \cdot 2 \%) \\
27 / 296(9.1 \%)\end{array}$ & $\begin{array}{l}13 / 155(8.4 \%) \\
15 / 152(9.9 \%) \\
28 / 307(9.1 \%)\end{array}$ & $\begin{array}{l}27 / 292(9.3 \%) \\
28 / 311(9.0 \%) \\
55 / 603(9.1 \%)\end{array}$ \\
\hline
\end{tabular}

larger families, however, come from the period before $\vec{T}$ 1900 , information on which is unreliable. A further source of bias is the influence of asymptomatic heterozygotes. Overall, however, the two groups appear comparable.

The group designated affected in the current analysis may not have been affected at the time of birth of their children and the information necessary

TABLE 8 An analysis of the numbers of children born to affected subjects in relation to onset of disease.

\begin{tabular}{lcc}
\hline & $M$ & $F$ \\
\hline Total number of children (T) & 507 & 487 \\
Number born after onset (a) & 44 & 16 \\
Birth timing unknown (b) & 89 & 105 \\
Number born before onset T-(a+b) & 374 & 366 \\
Mean family size: affected & 2.75 & 2.39 \\
Mean family size: unaffected & 2.47 & 2.24 \\
& $t=1.81$ & $t=0.28$ \\
& $0.1>$ p $>0.05$ & NS \\
\hline
\end{tabular}

TABLE 7 Age of parents at birth of first child (first) and the interval in years between first and last children (span) according to ultimate family size. The figures in brackets denote the number of families.

\begin{tabular}{|c|c|c|c|c|c|c|c|c|}
\hline \multirow{3}{*}{$\begin{array}{l}\text { Size of } \\
\text { family }\end{array}$} & \multicolumn{4}{|l|}{ Affected } & \multicolumn{4}{|l|}{$G l$} \\
\hline & \multicolumn{2}{|l|}{ Males } & \multicolumn{2}{|l|}{ Females } & \multicolumn{2}{|l|}{ Males } & \multicolumn{2}{|l|}{ Females } \\
\hline & First & Span & First & Span & First & Span & First & Span \\
\hline $\begin{array}{r}1 \\
2 \\
3 \\
4 \\
5 \\
6 \\
7 \\
8 \\
9 \\
10 \\
11 \\
12 \\
\end{array}$ & $\begin{array}{l}29.1(19) \\
30.3(18) \\
27.6(25) \\
24.7(12) \\
26.0(7) \\
26.7(10) \\
23.7(9) \\
16.0(1) \\
24.0(1) \\
22.3(3) \\
23.0(2) \\
26.5(2)\end{array}$ & $\begin{array}{l}- \\
5 \cdot 2(17) \\
8 \cdot 4(24) \\
10 \cdot 2(10) \\
10 \cdot 0(5) \\
14 \cdot 4(11) \\
17 \cdot 3(5) \\
13.0(1) \\
16 \cdot 0(1) \\
22 \cdot 2(2) \\
30.0(1) \\
22 \cdot 5(1)\end{array}$ & $\begin{array}{l}25 \cdot 8(17) \\
25 \cdot 2(31) \\
22 \cdot 1(12) \\
24 \cdot 3(16) \\
20 \cdot 8(10) \\
20 \cdot 9(9) \\
22 \cdot 1(9) \\
21 \cdot 7(3) \\
22 \cdot 0(1) \\
19 \cdot 3(3) \\
- \\
-\end{array}$ & $\begin{array}{l}- \\
4.4(29) \\
9.4(13) \\
12.8(16) \\
12.4(9) \\
16.1(5) \\
17.0(8) \\
18 \cdot 8(2) \\
22.0(1) \\
25 \cdot 2(2) \\
- \\
-\end{array}$ & $\begin{array}{l}29.4(14) \\
27.4(20) \\
27 \cdot 2(11) \\
22.0(2) \\
23.0(4) \\
20.0(1) \\
- \\
25 \cdot 5(2) \\
- \\
- \\
-\end{array}$ & $\begin{array}{l}\overline{4} \cdot 4(21) \\
7 \cdot 5(9) \\
17 \cdot 5(2) \\
13 \cdot 5(4) \\
19 \cdot 0(1) \\
\overline{14} \cdot 5(1) \\
- \\
- \\
-\end{array}$ & $\begin{array}{l}29.4(11) \\
24.5(24) \\
24 \cdot 8(8) \\
21.6(8) \\
26.5(2) \\
20.3(3) \\
\overline{19} .5(2) \\
24.0(1)\end{array}$ & $\begin{array}{l}\overline{4} \cdot 2(25) \\
10 \cdot 8(9) \\
12 \cdot 7(7) \\
14 \cdot 5(2) \\
15 \cdot 0(3) \\
\overline{20} \cdot 5(1) \\
14 \cdot 5(2)\end{array}$ \\
\hline
\end{tabular}


TABLE 9 Correlation coefficients for mean family size and age at onset of disease divided into 5-year periods of onset age.

\begin{tabular}{|c|c|c|c|c|c|c|c|c|}
\hline \multirow[b]{2}{*}{ Onset age } & \multicolumn{4}{|c|}{ Males } & \multicolumn{4}{|c|}{ Females } \\
\hline & No & Age at onset & Family size & $r$ & $N o$ & Age at onset & Family size & $r$ \\
\hline
\end{tabular}

to evaluate this is unfortunately fragmentary. For females some licence was taken. When onset was known to be later than 45 years and the dates of birth of children were unknown, an assumption of birth before onset was made. Nevertheless, in $17.6 \%$ of children born to male parents and $21.6 \%$ born to female parents, placement before or after onset was not possible. It is interesting that fewer than $10 \%$ of children were born after diagnosis.

A method of testing whether more children than expected were born before onset was devised (table 8 ). The resulting maximum number of children born after onset will inevitably lead to an under-

TABLE 10 Mean family size of affected subjects according to whether the first symptom was a mental change or a neurological syndrome.

\begin{tabular}{|c|c|c|c|c|}
\hline & \multicolumn{2}{|l|}{ Males } & \multicolumn{2}{|l|}{ Females } \\
\hline & Mental & Chorea & Mental & Chorea \\
\hline $\begin{array}{l}\text { No of families } \\
\text { Mean family size }\end{array}$ & $\begin{array}{l}50 \\
3.7 \\
t=0.6\end{array}$ & $\begin{array}{l}53 \\
3 \cdot 4 \\
\text { NS }\end{array}$ & $\begin{array}{l}43 \\
2 \cdot 8 \\
t=0 \cdot 17\end{array}$ & $\begin{array}{l}76 \\
2 \cdot 8 \\
\text { NS }\end{array}$ \\
\hline
\end{tabular}

estimate of children born before onset. The figures for affected females do not differ from controls, while for males the $t$ value approached $5 \%$ significance, hence the suggestion that more heterozygotes have more children before onset than expected.

The relationship of family size to age at onset was tested by calculating correlation coefficients for these parameters for all male and female heterozygotes, divided into 5-year groups of onset age (table 9). One significant negative correlation occurred in males under 35 years of age. However, three cases of early onset, at ages 23,25 , and 25 years, having six, seven, and five children respectively, had a strong influence, and, when removed, no association of significance was shown in any of the 5-year groups of onset age.

While there was no evidence to suggest that heterozygotes had manifest the disorder before the period of family building, the question of increased sexual drive as part of an initial mental change was assessed in relation to the mean family size (table 10). There was a large amount of unknown information but no results of significance were achieved.

TABLE 11 Relative fitness $(W)$ of choreics $(C)$, normal sibs $(N)$, general population $(P)$, and a control group (Con) from previous series.

\begin{tabular}{|c|c|c|c|c|c|}
\hline & & $w_{N}^{C}$ & $W_{P}^{C}$ & $W_{P}^{N}$ & $W_{C o n}^{C}$ \\
\hline \multirow[t]{2}{*}{ Panse $^{3}$} & Male & $(1 \cdot 32)$ & - & - & - \\
\hline & Female & $(1 \cdot 26)$ & - & - & - \\
\hline Kishimoto ${ }^{14}$ & Total & 0.65 & - & - & - \\
\hline \multirow{3}{*}{ Reed and Neel ${ }^{7}$} & Male & $(0 \cdot 89)$ & 0.69 & - & 一 \\
\hline & Female & $(1 \cdot 38)$ & 1.02 & - & - \\
\hline & Total & $(1 \cdot 15)$ & 0.86 & 0.77 & - \\
\hline \multirow{3}{*}{ Venters ${ }^{15}$} & Total & $0.95-1$ & $0.9-0.95$ & - & - \\
\hline & Male & - & - & - & $(1.08)$ \\
\hline & Female & - & - & - & $(0.83)$ \\
\hline \multirow{2}{*}{ Wallace and Parker ${ }^{10}$} & Male & $1 \cdot 11$ & 0.88 & 0.78 & - \\
\hline & Female & $1 \cdot 52$ & $1 \cdot 13$ & 0.74 & - \\
\hline \multirow[t]{2}{*}{ Marx 8} & Male & 0.99 & 0.95 & 0.96 & - \\
\hline & Female & $1 \cdot 39$ & 1.40 & 1.01 & - \\
\hline \multirow{3}{*}{$\begin{array}{l}\text { Shokeir }{ }^{9} \\
\text { Stevens }\end{array}$} & Total & 1.38 & $1 \cdot 14$ & 1.83 & $1 \cdot 18$ \\
\hline & Male & 1.03 & $1 \cdot 14$ & 1.03 & - \\
\hline & Female & 1.52 & 1.09 & 1.07 & - \\
\hline
\end{tabular}




\section{Discussion}

Unequivocal new mutations in $\mathrm{HC}$ are rare, but are known to occur, estimates from previous work of mutation rate being $9.6 \times 10^{-6}, 70.67 \times 10^{-6}, 14$ and $0.4-4 \times 10^{-6}$ mutations $^{5}$ per locus per generation. The indirect method of assessing mutation rate assumes fitness to be less than unity, which may not be the case in HC. Assessment of each possible mutant is thus necessary, based upon very meagre information. The resulting figure of $1 \times 10^{-6}$ mutations per locus per generation from our study, while comparable with other series, is not reliable.

If $\mathrm{HC}$ were to be maintained in the population solely as a result of mutation, then it would be a very rare disorder. Stevens ${ }^{5}$ has discussed the possible alternative diagnosis of new mutation, including non-hereditary chorea, offspring of an undetected carrier, or genuine non-penetrance and illegitimacy. If these possibilities are not excluded, then any new mutation is dubious.

Demographic methods of assessing fertility involve prospective surveys of marriage or birth cohorts. The present survey is necessarily retrospective, and past reproductive performance is assessed by fitness calculations. Relative fitness requires a control population and this can be a major source of error. Previous studies (table 11) have used normal sibs, the general population, sibs of affected persons' spouses, ${ }^{15}$ or an unrelated age and sex matched population. ${ }^{9}$ Normal sibs, however, may have fewer children than expected because of voluntary restraint $^{7910}$ (see table 10). The present study found that unaffected relatives had comparable family sizes to the general population, although the adjustment of date of birth cohorts to marriage cohorts to accommodate the population statistics may have produced a small error. The children of these normal sibs (G2), however, would be unlikely to restrain their reproductive behaviour, and the fact that they have similar numbers of children to their parents lends weight to the use of $G 1$ subjects as a control group.

In agreement with most previous series, persons in our study heterozygous for the $\mathrm{HC}$ gene tended to have larger families than expected. Using the 1900 to 1920 date of birth cohorts, fitness is greater than unity for both sexes, with between $127 \%$ and $150 \%$ of abnormal genes in males and between $132 \%$ and $134 \%$ in females being transmitted to the next generation. Relative fitness reflects these figures, adjusting for changing trends in family size. There was no evidence for any difference between the sexes, or between affected and unaffected groups, in the proportion of subjects remaining single.

The present study did not find that female hetero- zygotes were more fertile than males, in contrast with previous studies. ${ }^{35781014}$ There are methodological differences, however, and the present study stressed the need for near complete ascertainment and exclusion of asymptomatic heterozygotes, uncompleted families, and remote generations containing only one ancestor. The results of previous studies are clearly summarised by Hayden. ${ }^{16}$

The reason for heightened fertility in choreics is not apparent. It has been ascribed to increased sexual drive as part of a subtle mental change preceding any overt mental change. The present study finds no evidence to support this. Most of the children were born before onset, the mean family size $i$ having no association with mental change as the first symptom or, indeed, the age at onset itself. $\vec{N}$ The family building of heterozygotes is comparable to that of their unaffected sibs, except that heterozygotes carry on reproducing when their normal relatives have stopped. It is unusual for subjects with $\mathbb{D}$ $\mathrm{HC}$ to reproduce well into the course of their illness, and very few children were born after diagnosis. This, however, is a reflection of late diagnosis, rather $\overrightarrow{\vec{\theta}}$ than genetic counselling. On average, the gap $\infty$ between first symptom and diagnosis was 8 years. ${ }^{12} \omega$

The results of our own study, and most others from Europe and North America, contrast strongly with the markedly reduced fitness estimate from $\overline{0}$ Japan, ${ }^{14}$ a country where the prevalence is approx- $\stackrel{2}{\circ}$ imately one tenth that of European and North $\mathbb{Q}$ American populations. It is possible that social $\overrightarrow{\vec{O}}$ factors influencing marriage and reproduction in $\frac{3}{3}$ Japan may have had a major influence that has not $\mathcal{F}$ been present elsewhere, and it will be important to see if subsequent studies from Japan confirm this impression.

It is thus apparent that $\mathrm{HC}$ is maintained as a ${ }^{\circ}$ direct result of transmission of the gene and not 3 . to a significant extent of mutation. Any attempt to $\delta$ control the disorder must aim at reducing the number of births at risk. We have shown that this 을 can be achieved by non-directive genetic counselling $D$ of those at risk ${ }^{11}$ using genetic risks based upon a을 life table derived from our study population. ${ }^{17} \overline{\mathrm{N}}$ Close surveillance of those at risk also reduces the ब gap between first symptom and diagnosis, a measure $N$ that will not greatly affect the family size of these people, but is likely to have an effect on the reproductive pattern of their children.

\section{References}

2 Jelliffe SE, Muncey EB, Davenport CB. Huntington's? chorea. A study in heredity. J Nerv Ment Dis 1913;40: 796-9.

2 Bell J. Huntington's chorea. In: Fisher RA, ed. Treasury $\mathbb{\mathbb { D }}$ of human inheritance. Vol 4. London: Cambridge Uni- $\frac{P_{1}}{1}$ versity Press, 1934:1-77.

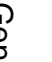
(n) 言 店 
3 Panse F. Die Erbchorea; eine klinishe-genetische Studie. Samml Psychiat Neurol Einzeldarst. Leipzig: Thieme, 1942:18.

4 Reed TW, Chandler JH, Hughes EM, Davidson RT. Huntington's chorea in Michigan. I. Demography and genetics. Am J Hum Genet 1958;10:201-25.

5 Stevens DL. Huntington's chorea. A demographic, genetic and clinical study. MD thesis, University of London, 1977.

6 Myrianthopoulos NC. Huntington's chorea. J Med Genet 1966;3:298-314.

7 Reed TE, Neel JV. Huntington's chorea in Michigan. II. Selection and mutation. Am J Hum Genet 1959;11:107-39.

8 Marx RN. Huntington's chorea in Minnesota. In : Barbeau A, Chase TN, Pawson GW, eds. Huntington's chorea, 1872-1972. New York: Raven Press, 1973: 237-43.

9 Shokeir MHK. Investigation of Huntington's disease in the Canadian Prairies. II. Fecundity and fitness. Clin Genet 1975;7:349-53.

10 Wallace DC, Parker N. Huntington's chorea in Queensland: the most recent story. In: Barbeau A, Chase TN, Pawson GW, eds. Huntington's chorea, 1872-1972. New York: Raven Press, 1973:223-36.

11 Harper PS, Walker DA, Tyler A, Newcombe RG, Davies K. Huntington's chorea. The basis for long-term prevention. Lancet 1979 ;ii :346-9.
12 Walker DA, Harper PS, Wells CEC, Tyler A, Davies K, Newcombe RG. Huntington's chorea in South Wales. A genetic and epidemiological study. Clin Genet 1981;19: 213-21.

13 Stevens DL, Parsonage M. Mutation in Huntington's chorea. J Neurol Neurosurg Psychiatry 1969;32:140-3.

14 Kishimoto K, Nakamura M, Togawa Y. Population genetics study of Huntington's chorea in Japan. Ann Rep Res Inst Environm Med (Nagoya Univ) 1957;9:84-90.

15 Venters G. Epidemiology of Huntington's chorea. PhD thesis, University of Edinburgh, 1971.

16 Hayden MR. Huntington's chorea. Berlin: Springer, 1981.

17 Newcombe RG. A life table for age at onset in Huntington's chorea. Ann Hum Genet 1981;45:375-85.

18 Wendt GG. Die Fruchtbarkett von Kranken mit Huntingtonischer chorea. Proceedings of the Second International Conference on Human Genetics. Amsterdam: Excerpta Medica, $1961: 1083-7$.

Requests for reprints to Professor P S Harper, Department of Medical Genetics, Welsh National School of Medicine, Heath Park, Cardiff CF4 4XN. 